\title{
Acid and Basic Open-Hearth Steel-making Practice
}

$\mathrm{T}$ HE annual meeting of the Iron and Steel Institute held on May 4-6 was devoted to a general discussion of open-hearth steel-making practice. A very large amount of data was brought together from all of the main steel-producing areas of the British Isles, and this material is most excellently summarized. As a result, it has been possible to determine in a manner hitherto impracticable the main factors on which high furnace efficiency depends.

It is confirmed that, within the working limits imposed by the refractory materials, etc., the output of a furnace is directly proportional to the heat input. For furnaces producing ordinary commercial steels, an average of $2 \mathrm{lb}$. of steel per hour per therm may be expected in the case of fixed furnaces and $\mathbf{1 \cdot 6} \mathrm{lb}$. for tilting furnaces. Large furnaces of the latter type show the lowest output of any of those examined, probably on account of the long period of refining required with the high percentages of hot metal employed. On the other hand, such furnaces have the advantage of a much lower consumption of refractory materials than obtains with other types of furnace.

For furnaces of normal port design, a high ratio of the velocity of the gas to the air gives the best performance, which requires that the area of the air port should be at least six times that of the gas port. Where this adequate gas/air velocity is obtained, conventional designs of the ports have given results which are as good as those obtainable with special constructions. Whilst the relative area of the hearth should be large when high proportions of scrap are being used, this factor of design is dependent on that of the ports and on the direction of the flame. On the other hand, when the percentage of hot metal is high and of high metalloid content, deeper baths are employed with correspondingly reduced areas of hearth.
The highest rates of production are shown to be obtained from basic, hot-metal, fixed furnaces, averaging 7.53 tons per hour per 100 tons capacity, a figure which may be compared with $7 \cdot 46,6 \cdot 49$ and 5.78 tons per hour for basic, cold-metal fixed; acid cold-metal fixed; and basic hot-metal tilting furnaces respectively. They have, however, a higher average total heat consumption per ton of $86 \cdot 2$ therms as compared with averages of $82 \cdot 8,84 \cdot 6$ and $76 \cdot 7$ therms per ton for the other types.

"With our ever-increasing knowledge of the subject the physical chemistry of steelmaking has becom $\theta$ of great importance in the operations of steel manufacture, and there are few sections of the industry to-day which have not benefited from the wider appreciation of the possibilities of this branch of applied science." Thus Dr. McCance introduces his paper on the application of physical chemistry to steel-making, in which he surveys the work done by himself and others in Great Britain, the United States and Germany. Starting with a general discussion of the basis on which this work has been built, the paper proceeds to direct attention to the more important conclusions already reached which have a direct bearing on the practice of steel-making by the open-hearth processes. The reduction of oxides by carbon; the manganese and silicon reactions; the reduction of manganous oxide by silicon; the reactions due to sulphur compounds and those in which phosphorus are involved are considered in turn, together with the question of ingot cracking.

Although the paper is unsuitable for further condensation here, it may be said without fear of contradiction that it represents the most substantial attempt ever made to consider any process of metallurgical production on a really scientific basis.

F. C. T.

\section{Scientific and Industrial Research in Canada}

$\mathrm{T}^{\mathrm{n}}$ WE twentieth annual report of the National Research Council, Canada, covering the year 1936-1937*, contains the report of the president of the Council as well as reports from the various divisions. Even the president's brief review of the organization of research, both pure and industrial, indicates that the work of the Council makes contributions to the progress of industry in Canada comparable with the contribution of the Department of Scientific and Industrial Research in Great Britain. The Division of Biology and Agriculture is devoting considerable attention to studies in the storage and transport of food. Valuable information obtained by visits to Europe during the year is being applied to the improvement of export trade arrangements. Simple and rapid methods have been worked out by the Division for determining the probable effectiveness of weed killers by their effect on the rate of growth of plants in water culture. A new method of experimental malting has been developed which

* 'Twenticth Annual Report of the National Restarch Council, 1936-1937. Pp. 182. (Ottawa: National Research Council of Canada, 1938.) 75 cents. seems to give the true value of varieties of barley, even though these require widely different malting conditions to give the best results. A new paper box packing has been developed for storing and shipping poultry, which can be sealed conveniently to prevent loss of moisture and the danger of freezer-burn. Apparatus has been developed for accurate measurement of atmospheric humidity at low temperatures and when only small amounts of moisture are present in the air. Work has been carried out on the relation of bacteria to the curing and to the uniformity of cured bacon, and other work has been carried out by the Division on the baking quality of wheat and in co-operation with the Canadian National Railways on a method of heating refrigerator cars which has led to the development of an underslung charcoal heater.

The Division of Chemistry has developed a relatively cheap synthesis for $\alpha$-naphthylacetic acid as well as methods for the synthesis of indolyl-butyric acid and indolyl-acetic acid. A fundamental study is being made of the problem of corrosion, and further 
work has been carried out on the novel form of distillation, which was invented by the Division, arrangements having been made for the manufacture of the gauze packing. Research on plastic casein has also been undertaken and research on the preparation and properties of carbon black from waste gases from the pyrolysis of natural gas has been concluded, while further work has been carried out on the preparation of carbon black by the channel process. Work on the use of formalin for the disinfection of seed wheat has been extended to include the study of many organic compounds as seed disinfectants. Good progress is reported in work on the fundamental laundrying operation bleaching, as well as in work on the fading of dyed textiles in sunlight, determination of damage to silk by a viscosity method and the regain of raw wool.

In the Division of Mechanical Engineering, the Aerodynamic Laboratory has carried out tests on models of three service aircraft in the wind tunnel to prove the accuracy of prediction of the performance of aircraft from the results of wind tunnel tests. Comprehensive wind tunnel tests have also been made for a Canadian aircraft building firm in connexion with the development of an aeroplane being designed specifically for commercial service in Canada. Measurement of hydrodynamic forces on stop logs for emergency dams in ship canals was a new and interesting study commenced during the year. Other problems under investigation include the work on fire hazard testing, farm windmills, gasolene specifications, aireraft instruments and the inspection and labelling of oil burners. The Division of Physics and Electrical Engineering has undertaken fundamental work on light, sound, heat and electricity as well as standardization in these and in related fields. The development of an improved and highly satisfactory means of heating refrigerator cars in winter which makes it possible to maintain uniform temperatures in the cars is now being taken up com. mercially. Studies in heat transfer are being applied to the tests in insulating material and to the investigation of heat conservation qualities of textiles used for clothing. Tests are also being made to determine the sound absorptive properties of building materials and the proper design of rooms for the best acoustical effects. Other experiments have been concerned with electrical methods of packing poultry in preparation for marketing. A second cathode-ray direction finder was built during the summer, and a development programme to adapt this type of radio direction finder to commercial service has been undertaken.

In addition to the work of the various Divisions, important work has been carried out through the joint or associate committees, including research on the breeding of rapid growing rust-resistant strains of wheat, oil seeds research, feeding-stuffs research, investigations on seed treatment with formaldehyde, on the effect of environmental factors on wool, on deficiency diseases of sheep, on asbestos, etc. The Associate Committee of Parasitology has been responsible for studies of liver fluke disease, warble fly eradication, anthelmintics, etc.

\section{Explorations of the Smithsonian Institution, I937}

$\mathrm{I}^{\mathrm{N}}$ the annual review of the research activities in the field of the Smithsonian Institution, Washington, D.C. ("Explorations and Field-Work of the Smithsonian Institution in 1937". Pp. 122), a preliminary announcement is made of the results of twenty-four expeditions, for the most part in geology, biology and anthropology. Some of these were financed wholly by the Institution, others were cooperative undertakings with institutions interested in the promotion of these respective branches of science. Most of the expeditions in 1937 were within the American continent, including the West Indies. Of the expeditions to other continental areas, Mr. H. G. Deignan describes an exploring expedition to Siam for the purpose of observing and collecting specimens of the fauna.

An expedition to the East Indies in conjunction with the National Geographic Society led by Dr. W. M. Mann visited Sumatra, Amboina, the New Guinea coast, Java, and Singapore, collecting living animals, birds and reptiles for the National Zoological Park. The minerals of Russia were investigated by Mr. E. P. Henderson, who visited the Kola Peninsula before attending the International Geological Congress at Moscow. The American expeditions and investigations included catching walrus pups in Greenland and moose hunting in Alaska, collecting insects in the West Indies and Virginia, fossils in Michigan, Utah, Arizona and elsewhere, and studies of the Montagnais-Naskapi Indians of the St. Lawrence river. Among the archæological investigations an account is given by Mr. David I. Bushnell, jun., of an ancient site on the banks of the Rapahannock in Virginia, exposed by flood water in the early months of 1937 , which produced stone implements of varied types and pottery bearing the impression of coiled backetry, considered to be the oldest form of pottery found in the Rapahannock valley. Other village sites of a similar character, and exposed by the same agency, were visited, which suggest that much instructive evidence would be obtained by systematic excavation. Further investigations on the Lindenmeier stone age habitation site in northern Colorado have produced evidence of importance relating to Folsom man, though the skeletal remains of this early type of man in America still evade search. Dr. F. H. H. Roberts, jun., who describes the results of his investigations here in 1937, records the discovery of a number of anvil stones still in situ, on which Folsom man manufactured his implements and cracked bones for marrow, as is shown by the fragments of various kinds of stone and bone found in the surrounding ground. The stratified deposits show that the site was occupied after the climax of the Wisconsin period, but within the late Glacial, when a colder and moister climate, which was responsible for the heavy soil zone overlying the evidence of occupation, was approaching. Dr. Aleš Hrdlička adds details relating to his investigations in the Aleutian islands of the problem of the migration of early man into America further to those already reported (see NATURE, 140, 577). 